\title{
You Eat What You Are: Identity Via Cannibalistic Food Ethics In Ying Chen's Le Mangeur
}

\author{
Julie Robert, University of Technology, Sydney
}

\begin{abstract}
Mon père m'avait très tôt avertie que nos semblables étaient les plus redoutables. La guerre se révèle toujours la plus atroce entre individus d'une même espèce. Nous sommes ce que nous mangeons, disait-il, nous mangeons ce que nous sommes.
\end{abstract}

(Chen 2006: 17) ${ }^{1}$

Like many migrant authors, the Shanghai-born Québécoise Ying Chen uses food and eating as a way to probe questions of identity. Her 2006 novel, Le Mangeur, explores a variety of shocking consumption practices and the values attached to each as it documents a daughter's attempts to understand who she is both in relation to and distinct from her father and the heritage he represents. As Chen's narrator wrestles with the desires and choices related to both her own and her father's eating, she struggles with the implications of very common question, namely whether or not we are what we eat.

Rather than approaching this question, as many migrant authors do, by using food metonymically to refer to places or cultures left behind and to thus reinforce the link between food and identity, Chen almost deliberately avoids and frustrates these common associations. The ahistorical, geographically and culturally imprecise setting her characters inhabit functions as a bubble in which all but the most basic principles

\footnotetext{
${ }^{1}$ Early on, my father warned me that those who were most similar to us were the most formidable. War proves to be the fiercest between those of the same species. We are what we eat, he said, we eat what we are.

PORTAL Journal of Multidisciplinary International Studies, vol. 10, no. 2, July 2013.

Edible Alterities: Perspectives from La Francophonie Special Issue, guest edited by Angela

Giovanangeli and Julie Robert.

ISSN: 1449-2490; http://epress.lib.uts.edu.au/ojs/index.php/portal

PORTAL is published under the auspices of UTSePress, Sydney, Australia.
} 
with regard to food and consumption are absent. The characters, human-fish hybrids, nonetheless grapple with the link between eating and identity. Their reflections on their food choices highlight an attempt to eat in a principled manner that founds itself on their own particular and embodied situations. The confluence of ambiguous cultural referents and an exaggerated physicality centred on the body and its practices of eating create the impression that in this surreal world of cannibalistic hybrids, eating is a way of understanding who we are, first and foremost, as beings whose food-related choices flow from their own embodiment.

I propose to understand Chen's privileging of the body in these concerns about food and identity through the notion of Foucauldian ethics (Foucault 1997). In this tradition, embodiment and the relation one has with oneself determines the kind of care for the self that one should exercise. By arguing that notions of edibility spring from the body and not larger cultural or even moralistic dictates, the supernatural premise of Chen's tale incites a radical rethinking of the relationship between food, culture, embodiment and identity. The divestment of food from conventional notions of culture, particularly as Chen has become a canonical writer in Quebec's tradition of écriture migrante, begs many questions. ${ }^{2}$ I would argue that chief among these concerns is whether or not we have over-invested in the notion that food is emblematic or even constitutive of identity, especially in migrant writing.

In lieu proposing definitive answers, such queries might best be regarded as provocations. Given that Chen's characters unsettle the binaries of living and dead, human and animal, edible and inedible implicit in questions of food in general, cannibalism in particular, and of the questions of identity inherent to both, Le Mangeur challenges its reader to fully consider the implications of Brillat-Savarin's famous aphorism that we are what we eat: 'Dis-moi ce que tu manges: je te dirai ce que tu es' (1826). ${ }^{3}$ These provocations urge readers to rethink not only their relationship with (their) food, but also a literary and cultural tradition that has made food a central trope in the positing of identity.

\footnotetext{
${ }^{2}$ Écriture migrante refers to writing by authors who migrated to Quebec. Typically, the term refers only to those who have chosen to write in French. Within the province's literary scene, authors from Haïti (Marie-Célie Agnat, Dany Laferrière, Emile Ollivier), Italy (Antonio D’Alfonso, Marco Micone, Bianca Zagolin), various countries in the Middle East (Wajdi Mouawad, Naïm Kattan, Abla Farhoud, Nadine Ltaif) and Asia (Ying Chen, Ook Chung, Kim Thúy) figure prominently.

${ }^{3}$ Tell me what you eat, and I will tell you what you are.
} 


\section{The eater and his daughter, the wife}

Chen's seventh novel, Le Mangeur, is probably her most disconnected from any sense of reality. The tome's fantastical nature is most obvious in the mysterious ambiguity of the narrator, who had appeared in more human form in earlier works. This narrator, like the narrators in the earlier texts, speaks with two voices and has thus been construed to be a single character: a woman with a mental illness. ${ }^{4}$ Representing different personas, the nameless narrators exist in separate yet overlapping temporal dimensions and are best differentiated by the roles they play, which is to say, the daughter and the wife.

Of the two, the daughter is the 'imagined' narrator; and what happens to her, namely being eaten by her father in an act of endogamous cannibalism, can be seen as a ficitonalized product of the wife-narrator's abnormal psychology. In the world that the daughter inhabits, however, she is a nineteen year-old who lives with and cares for her ailing father, whose greatest concern is having enough food to satisfy his voracious appetite. Both father and daughter are described as having a genetic illness, although this would more accurately be a sort of hybrid physiology, that causes them to become increasingly fish-like in appearance and behaviour as they age. This ailment, the result of a great-grandmother's coupling with a large fish, caused the mother to flee and precipitates the father and daughter's gustatory insatiability. Their hunger also resultsboth directly and indirectly_in the father eating his daughter. ${ }^{5}$

The wife, the 'real' narrator, is a slightly older woman who lives with her husband, identified only as A. Her memory of her childhood and adolescence is fragmentary, but is connected to her father and their home via the family appetite and illness, the latter an element of the imaginary existence that pervades her 'reality.' The wife (according to the logic of the daughter's recounting of events) came into existence as a result of the daughter's apparent death in the earlier narrative, her demise having been caused by the

\footnotetext{
${ }^{4}$ This strategy is also employed in Querelle d'un squelette avec son double (Chen 2003), a novel that features a version of the narrator from Le Mangeur, albeit this time incarnated, in the first instance, as a severely anorexic woman with agoraphobia and anxiety, and in the second, as a starving woman trapped under the rubble caused by an earthquake. Lorre (2009: 21) regards all these narrators (who are present in no fewer than four of Chen's novels) as highly influenced by their psychological troubles. I would draw attention to the fact that in all their iterations, these narrators have complicated relationships with food, in that it is either refused, desired without fulfilment, forms the basis of a bond or is consumed to excess.

${ }^{5}$ Lori Saint-Martin (2010) argues that contemporary Québécois texts about father-daughter relationships are often marked simultaneously by excess and lack and this binary is most certainly operating in Chen's text in relation to food. She notes that this pattern is especially common in cases where the relationship is incestuous. Given the associations between cannibalism and (oral) sex (Sceats 2000; Probyn 1999), incest always lurks as a possible explanatory reading.
} 
cannibalistic act. This act, as recalled by the daughter in a sort of time-travelling passage through her father's digestive tract, ties the two narratives together and serves as the principal narrative hinge for the story.

The ambiguity that defines Chen's narrators finds its analogue in indistinct temporalities and settings. Beyond a few clues about technology such as trains and telephones, which would suggest the action takes place in the 20th or 21st century, readers cannot locate the action in time. The geographic settings are similarly vague, described only by generic locales: a house by a river, a grocery story, a butcher shop, an art gallery and a train. In this, Lorre (2009: 20) notes, Chen breaks from the geographic realism of her earlier novels, such as Les Lettres chinoises (1993), and migrant writing more generally. Jack Yaeger nonetheless argues (2004: 141, 143) that this lack of precision signifies an existence between cultures, temporalities, and subjects that is at the very core of the migrant's experience of diasporic life and cultural hybridity.

Although the existence between cultures is a stock storyline of écriture migrante, the existence between species is Chen's hyperbolic and surreal variation on the theme. The body-bound nature of this particularity is of central importance in the text. Chen diligently enumerates (in occasionally sickening detail) the implication of her characters' surreal genetic in-betweenness. The daughter's self-description, while not fully cataloguing her anomalies, conveys their unique qualities: 'Mes quatre membres étaient plus courts que la normale. J'avais des yeux globuleux aux prunelles minuscules, une mâchoire pointue et élancée qui se confondait presque avec le nez à peine existant sauf deux assez grandes narines, une peau humide, constamment froide et portant une odeur de sang' (Chen 2006: 8). ${ }^{6}$ Father and daughter also experience progressive difficulty in regulating body temperature (12), and have skin so dry and scaly it necessitates 5 to 6 baths a day $(11,34)$. Their dermis has a pinkish hue with darker pink splotches (84). They have small pointy teeth (84). Their appetites become more and more voracious and this, unsurprisingly, results in rapid weight gain in the latter stages of their shortened lives (34). Both protagonists are also described as extraordinary swimmers (9), a fact demonstrated in their daily fishing rituals in which they strip naked, jump into the river and catch (with only their mouths) the fish that will serve as their

\footnotetext{
${ }^{6}$ My four appendages were shorter than the norm. I had protruding eyes with miniscule pupils, a pointed jaw that jutted forward that flowed indistinctly into my nose, itself almost non-existent save two rather large nostrils, and clammy skin that was always cold and which smelled of blood.
} 
dietary staple. The focus on corporeality here supplants abstract notions of (cultural) hybridity and makes the body the locus for the related questions of identity. As an essential part of any embodied existence, eating therefore becomes part of the process of identity formation.

\section{Divorcing food from culture}

For scholars working in food studies, food and culture are enmeshed. Food's role in coming to know the Other and in articulating a sense of self are key issues of the field, particularly in the context of multiculturalism, diaspora and migration-situations analogous to Chen's. In such contexts, food is frequently ascribed the role of keeper of traditions or a sense of home (Ang 2004). Most often this is done with reference to a maternal figure’s cooking (Goldman 1992; Heller \& Moran 2003). In Quebec’s tradition of écriture migrante, food frequently functions in this way, as it is both a means to fondly recall other places and cultures and to position oneself relative to the new situation (Mata-Barreiro 2003). Eating foods from one’s ‘own’ culture is a way to perform this cultural identity, especially among those living in diaspora (Hubbell 2013). The notion of 'eating the Other' has similarly marked explorations of 'ethnic food,' for in eating the 'Other's' food, the consumer enacts an identity of cosmopolitan sophistication (Flowers and Swan 2012; hooks 1992; Goldman 1992; Finn 2011).

When food is used in these symbolic ways, be they nostalgic or neo-colonial, specificity and detail are key. In order for food to be 'an affirmation of cultural specificity and autobiographical presence' (Goldman 1992: 174), it must be evoked in terms that place it beyond sustenance —-food's most basic and universal function —and locate it in a particular cultural context. Coffee, for instance, a seemingly generic substance, has emerged as a powerful symbol of home for Haitian novelists in Quebec, for the beans, the way of preparing the beverage and its taste are all painstakingly contrasted (negatively) to what is on offer in Quebec (Mata-Barreiro 2003). Detailed descriptions of recipes, remembrances of preparations or the sensorial and affective experiences of eating certain foods in a particular context consequently figure prominently in much of the writing (migrant or otherwise) about food. The thriving business of 'food as culture' after all markets itself with close up visuals, sensuous rich descriptions and anything else that conveys what exactly awaits the diner. 
Food is indeed fundamental to Chen's narrative, but the ways in which it operates disrupts the typical scripts of maternal links and cultural connections. In the first instance, the mother is totally absent from the narrative, so food serves to bond father and daughter: 'Cuisiner était notre passion commune, un sujet de conversation intarissable' (Chen 2006: 39). ${ }^{7}$ In light of the cannibalistic conclusion of this relationship, however, it is quite reasonable to argue that the generational bond secured by food is, at the least, problematic. ${ }^{8}$

Beyond this food-related illustration of the 'too close' relationship between father and daughter, the novel more importantly subverts expectations with regard to specificity and the importance of food for a given group. The narrator mentions broad categories of food more than specific dishes, and preparations, described minimally if at all, do not situate food relative to any discernable culinary tradition. Fish is either cooked or uncooked, procured either fresh or frozen, but recipes (despite the fact that the house has an extensive collection of cookbooks) are never revealed. This conspicuous silence is echoed in the utter lack of detail in describing other consumables. The animal provenance of the 'chops' (veal? pork? lamb? mutton?) is never mentioned, the confections bought from the shop across the street are not elaborated upon, and the only precision about the tea is that it is of the loose-leaf variety. The most detailed descriptions are vague reports about a chicken being cooked in the oven after having been seasoned with salt and wine (Chen 2006: 53) and a stock being made with 'meat' and unidentified vegetables (43). Like the generic locales and the sense of near timelessness that fail to anchor Chen's narrative, the food similarly contributes to a feeling of cultural imprecision that subverts even the typical 'migrant ambiguity' that Yaeger (2004) attributed to the indistinct setting. Rather than being emblematic of the migrant experience, food fails to perform as a trope of larger cultural belonging, memory, a feeling of being between cultures or even exoticism of the migrant experience. Rather, it anchors itself only in the bare physicality of the act of consuming. The distance that Chen imposes between food and typical cultural scripts about cuisine is in many ways a function of the novel's surreal qualities and characters. As beings that

\footnotetext{
${ }^{7}$ Food was our shared passion, an inexhaustible subject of conversation.

${ }^{8}$ Saint-Martin (2010: 27) observes that until the mid-1970s, fathers in North America were largely thought to be incapable of 'nurturing' children, a function that covers both care in a general sense and the provision of food.
} 
are not fully human, they are given allowances to regard their food differently. In describing the father's ritual for catching the fish that form the staple of the family diet, for instance, his own fishiness comes to the fore: 'Parfois une prise déjà hors de l'eau pouvait aussi, épouvantée, se sauver. Alors mon père ne pouvait se retenir. Il exécutait une plongée dont la force de l'élan aurait ébahi des athlètes olympiques. Il ressortait de l'eau avec entre ses dents pointues le poisson ensanglanté et à demi mort' (Chen 2006: 9). ${ }^{9}$ This description, accentuating the father's prowess as a hunter, places him into an ecological and naturalised understanding of consumption whereby bigger fish eat smaller fish. What might otherwise be construed as cannibalism (of the fish-on-fish variety) is thus stripped of its negative cultural connotations, for as brutal as nature may be, there can be nothing transgressive about this kind of eating. Chen's play with the nature-culture divide-evidenced by using a reference to an Olympic athlete to describe animalistic attributes and skills — does not place her protagonists outside of a cultural field, but it does privilege eating in ways that are unmediated not only by a specific set of cultural practices, but by any sense of humanity. Echoing anthropologist Mary Douglas, who protests the symbolic over-investment in food by reminding us that 'food is not only a metaphor or vehicle of communication; a meal is a physical event' (cited in Symons 1994: 339), Chen prioritises embodiment and physicality in her treatment of eating.

Indeed, one of the most common referents for food in Le Mangeur is that of bare physical need: hunger. As Johnston and Baumann (2010: 139-40) rightly note, hunger is an aspect of discussions about food that is largely relegated to the sidelines in the North American context. Chen's foregrounding of hunger might be construed as a culturally decentring reminder (particularly to North American readers) that hunger is the defining facet of many people's relationship to food. ${ }^{10}$ Her characters' staggering caloric intakes nonetheless reinforce the fantastical nature of the text and therein trouble logical or extra-textual understandings of hunger. By way of illustration, in the half day that provides the timeframe of the daughter's narration and the apogee of the father's appetite, he consumes a large bag full of fish, three pieces of meat, a whole chicken and,

\footnotetext{
${ }^{9}$ Sometimes one that had already been taken out of the water would, terrified, escape. In those cases, my father couldn't restrain himself. He dove in with such force that Olympic athletes would have been astonished. He surfaced, holding between his pointed teeth, the fish, bloodied and half dead.

${ }^{10}$ Gang Yue (1999) also notes that the theme of hunger was prominent in Chinese literature and culture throughout the $20^{\text {th }}$ century.
} 
finally, his own (adult) child. These unreal ingestions are nonetheless justified in highly biological terms, namely via the somatisation of appetite. The father's insatiable hunger is likened to a consumptive's gasping for breath (Chen 2006: 39), a comparison that impresses the exigency of his need upon the reader and legitimates it in a way that makes it more both more 'human’ and closer to the experiences of Chen's first-world Québécois audience than starvation. ${ }^{11}$ This is possible because of the 'sick role,' which extends certain privileges to the ill and spares them from normal social duties and constraints (Parsons 1951). To do so renders this particular anthropophagy as the cannibalism that is not cannibalism, but rather 'a response to extreme circumstances' (Kitson 2000: 8), for the sick role temporarily absents the person who is ill from society and its obligations. This cannibalistic consumption exists outside of culture not because it is rejected as beyond what the 'civilised' do, but because the body and its needs take precedence over cultural considerations.

Unlike dietary prescriptions that are based on religious or cultural norms (which can create or be used to identify a particular culture or community), the characters' stances on what is edible seem to be based almost entirely on notions that stem from their physicality. Referring both to taste and sensibilities of various kinds, such as what is deemed (either by oneself or others) to be healthful, wholesome or moral, 'the edible' is a term that opens itself to many interpretations. Untethered to a broader cultural understanding of food, however, the characters formulate an alternative and highly particular sense of the edible that privileges physicality and circumstance over cultural codes, norms or mores. This focus on the aspects of food that situate it more outside of cultural spheres of influence than in them calls for a rethinking of not just what is considered edible, but also of the systems and rationales through which such determinations are made.

\section{Ethical eating}

Although eating is a biological imperative, various forms of 'food ethics' or 'ethical eating' have made it subject to cultural codes that determine what we should and should not eat. Whether it be religious prescriptions that directly link morality to food via notions of purity (kosher or halal diets), or practices of cruelty-free (vegetarian or

\footnotetext{
${ }^{11}$ The mythology of the tubercular body as that which consumed itself is apt but dislocated in Chen's narrative, for although a body is consumed, it is the body of she who is external to the afflicted party.
} 
vegan), natural (organic, raw or unprocessed), healthy (neither too much nor too little, nutritious) or ecologically sustainable eating (locavorism), ethics and eating increasingly go hand in hand. Contemporary food ethics are largely framed in terms that privilege morality and normative behaviours aimed at notions of right and wrong in cultural, environmental, social justice or animal rights terms. ${ }^{12}$ Taken in this way, food ethics have tended to revolve around what Diprose terms 'setting down a set of universal principles for regulating behaviour' (1994: 18). Given that food is subject to so many contested and even competing ethical codes, it is no surprise that it has been difficult to formulate, much less adopt, any universal ethical stance when it comes to eating. Different cultural groups nonetheless prioritise certain formulations of ethical eating and these prescriptions come to prevail within a given group. These dominant rules for eating serve, at least within the group, as universalising determinations about what is and is not edible and the basis for behaviours of belonging.

In contrast to such collectivist attitudes toward food, Probyn (1999) argues that eating, when considered in ethical terms, is more appropriately framed by Foucault's concept of ethics than any moralistic sense of the word. Referred to as technologies of the self, ethics are the practices that we perform as part of a deliberate and reflective existence. Posited as 'the government of the self by oneself in its articulation with relations with others,' and said to encompass 'the prescription of models for living,' such as diet (Foucault 1997: 88), this understanding of ethics foregrounds 'the embodied differences between individuals’ and entails ‘being in the world' (Diprose 1994: 18). For Diprose, being in the world is about positioning oneself in time and space, a process that brings the body and embodiment to the forefront of any ethical concern.

Chen's novel, although it denies its readers any sense of temporal or spatial location (and in so doing effectively eliminates a great many concrete cultural referents), puts the body at the core of a personal rather than a collective ethics of eating. The characters continually articulate what is and is not edible based on their (similar) embodied states. The narrator and her father, for instance, share great hungers and abnormal physiologies that have them prefer fish to any other kind of food (Chen 2006: 13) and view anthropophagy as acceptable. Yet the father's more ravenous condition eventually has

\footnotetext{
${ }^{12}$ Concerns about food's impact upon the body have, however, increasingly come to be seen as part of social obligations around consumption. Finn (2011) argues that conscientious eating of various forms, especially among the self-styled middle class, has become an accessible marker of social capital.
} 
him view chewing one's food as a form of cruelty (53), whilst the wife's more moderate hungers have her privilege chewing and swallowing as the most pleasurable aspects of eating (108). Where the body is 'the site of one's habitat and subjectivity-where the body is constituted by a dynamic relation with other bodies in a social context of power, desire and knowledge' (Diprose 1995: 162), the characters use their bodies to formulate an ethics of eating. This pertains both to the manner in which food can be consumed and to the very definition of what is and is not edible, for the characters weigh orders of physical and ontological similarity to and difference from potential food as an indication of whether or not it is consumable. What therefore emerges is an understanding of eating and the edible that is intrinsically rooted in the protagonists' exceptional embodiment rather than in any conventional sense of cultural belonging or alterity.

I would pause momentarily to clarify that the body is and remains a cultural object and is responsible for myriad processes with deep cultural significance. In contemporary discourses, however, the body's physicality tends to be asserted and emphasised to deliberate effect and not as a matter of course. ${ }^{13}$ As Drew Leder (1990) contends, the normally functioning body and its processes, particularly in tasks as mundane as eating, tend to be lost to our perception. Only when something is dysfunctional or abnormal does the body make itself known. For this reason the physicality of eating in Chen's novel is so shocking: 'Nous marchions vite. Les poissons s'agitaient dans le sac bien fermé. Nous courions presque, tremblant déjà du plaisir de tuer et d'avaler nos proies, de sentir leur sang couler le long de notre gorge, avec ce goût de terre du fond de la rivière persistant dans notre palais’ (2006: 15). ${ }^{14}$ What is striking is the sensuality of the experience. Taste, smell and the pleasurable sensations of killing and ingurgitation are celebrated and the facets of food production and consumption that are purposefully ignored in other contexts—-killing, swallowing, blood—are emphasised. Chen's privileging of the eating subject's embodied physicality calls attention to the bodyspecifically these extraordinary bodies that exist in a narrative environment devoid of cultural markers—and its role in determinations about edibility.

\footnotetext{
${ }^{13}$ Protests by disability rights advocates for more accessible infrastructure and greater legal protections against discrimination, for instance, have seen people who would normally use wheelchairs and ramps dragging themselves up the steps of inaccessible government buildings. This call to observe the body struggling against the built environment is the deliberate aim of the protests.

${ }^{14}$ We walked quickly. The fish were restless in the tightly closed bag. We were on the edge of running, already trembling with the pleasure of killing and swallowing our prey, of feeling their blood flow down our throats, the taste of river-bottom silt lingering on our palates.
} 
Chen's implicit project might therefore be construed as rejecting the commonly defined moralistic or culturally defined basis for food ethics and foodways more generally in favour of an ethics of eating that issues primarily from embodiment. Although migrants to North America have customarily used 'different cultural frameworks to address ... issues around eating' (Johnston, Szabo \& Rodney 2011), the uniqueness of the characters (there are only two of their kind) and their appetites makes this notion of different frameworks so hyperbolic that any generalised 'migrant's ethics of eating' seems an incommensurate explanation for their unusual practices and ethical justifications. Food ethics in the novel are so particularised that the only point of reference is the body and the sensibility to it developed through a troubled fatherdaughter relationship. Although this situation is striking in its aberrance, it is also somehow in keeping with certain facts about eating. As Simmel (1994) argues, eating (as opposed to dining) is fundamentally an individual act. It is about taking in food that once ingested becomes ours and ours alone. Eating may be done with others in communal settings, but our food is proper to us and is never collective or cooperative. Our food may therefore tell us something about ourselves, but it does not necessarily assist us in understanding who we are in relation to those around (or even like) us.

\section{Cannibalistic and hybrid food ethics}

If we accept that in a Foucauldian understanding of food ethics the body is the locus for determinations about what is and is not edible, and we accordingly acknowledge that the bodies in Chen's narrative are exceptional, it stands to reason that determinations about what is and is not edible are similarly likely to stand apart from food ethics that privilege recognisable cultural norms or values. Indeed, the focus on embodiment enables instances of innocuous, mundane eating to be called into question and qualified as ethically dubious practices whilst nearly universal taboos-namely cannibalism—are justified and rendered acceptable. How then does a focus on embodiment in the elaboration of a personal food ethics allow for new understandings of how our food choices might both reflect and consolidate our identity?

One of the implicit principles of a universalising food ethics, even when not defined in ways that restrict the term to its popular contemporary uses, is that we do not consume that which is closest to us. This prescription has not only been used to prevent cannibalism, but also puts animals such as family pets off limits. In the discourses about 
why this is so, Derrida (1991) and Anderson (2010) privilege subjectivity. Because humans (and anthropomorphized animals like pets, i.e. those considered 'part of the family') are construed as rational subjects, they play a social role and are thus spared from an alimentary one. As Anderson puts it: “The construction of “distance” between human and animals (and thus subject and other more generally), works to justify the status of the subject as different from the animal, and thus in turn, justifies killing and eating animals’ (2010: 69-70). Others, like Pugh (2008), have concerned themselves more with orders of biological or physical similarity to determine whether or not there is the requisite difference between an eater and its food to avoid allegations of cannibalism.

At stake in both of these ways of understanding the edible, whether they privilege embodiment or less corporeal criteria, is a notion of relativity that is predicated on relationships of similarity or difference. As Guest argues, the boundaries that differentiate the ethical eater from the unethical cannibal 'may in fact be more productively read as a symbol for the permeability, or instability, of such boundaries' (2001: 2). For Chen, whose characters are both human and animal, the carnivore/cannibal distinction proves to be not just unstable, but utterly inoperable, for the 'neither inhuman nor fully human' that for Yue (1999: 25) defines the cannibal provides the precondition of all their eating, not the result of an exceptional cannibalistic act. Chen's characters are hence granted both the allowances for animalistic eating - one that cannot be subject to ethics of any kind — and constrained by restrictions around food, which in one form or another, characterise nearly every culture. Although the concepts of similarity and difference still prevail as the principle underlying these food ethics, the human-animal boundary collapsed by the characters' lineage and the narrator's status as both living and dead enact new ways of conceiving of and valuing embodied similarity and difference in terms of edibility.

For his part, the father relies on relatively traditional distinctions to ground his food ethics, for he objects to consuming other mammals. 'Nous avions donc évité autant que possible le contact, ne serait-ce que visuel, avec la viande provenant de mammifères’ (14). ${ }^{15}$ The implicit principle, as explained by his daughter, is that meat is too close to

\footnotetext{
${ }^{15}$ Whenever possible, we therefore avoided contact, even visual contact, with meat coming from mammals. Curiously, Chen does not employ the term chaire which connotes meat, vegetable and human flesh, but instead opts for viande, a term that in Mandarin shares the same word with the similarly multiple-meaninged flesh.
} 
the father's conception of himself as a mammal for him to feel comfortable eating it. The seven-eighths of him that is human therefore holds sway over his octoroon fishiness and steering him, at least before hunger outpaced conviction, toward pescatarianism. That he can nonetheless consume the only being that is like him elevates his hunger to the position of supreme identifier of and decision-maker about edibility.

For the daughter, on the contrary, the relatively unexplored facet of embodiment and food ethics, the differences of life and death, serve as the basis for differentiating food from inedible matter. Commenting on her father's consumption, she expresses disdain for what most of us take for granted in all but the most adventurous and/or costly of dining experiences, namely that our food is dead when we consume it. ${ }^{16}$ As she puts it: 'Il lui fallait du poisson à chaque repas. Quand il n’y en avait pas de vivants, il se contentait des cadavres touvés au marché ou dans le congélateur d’un grand magasin. C’était désolant, car pendant les dix-neuf ans de ma vie nous n’avions jamais daigné toucher à un poisson mort' (13). ${ }^{17}$ The father’s hunger makes eating frozen and then cooked fish acceptable, but the still relatively 'healthy' daughter finds the practice revolting, an odious necrophagy akin to scavenging. For her, even the most anodyne and normalised of foods, tea leaves, are described as bits of once living things that having released their flavour become valueless corpses in the cup (103). The repetition of the morbidly clinical descriptor 'cadaver' lends a human-like dimension to what most among us would see as simple produce or, at the limit, animal flesh. The daughter's comments, in that they evoke the abject quality of eating the dead, recall Levi-Strauss's contention that eating any organic matter that did not die a natural death unrelated to becoming food is, in a sense, a form of cannibalism (1969).

The living-dead distinction proves so central to the daughter's sense of food ethics that she is able to make even her own devouring seem more acceptable than her father's eating of the (dead) chicken she had been preparing him. In recounting how her father

\footnotetext{
${ }^{16}$ I am thinking here of dishes like Japanese ikizukuri (live sashimi), Korean sannakji (live baby octopus), or the live shrimp dish on acclaimed Danish restaurant Noma's menu, which all connote both exoticism and prestige for the diner. Eating live food need not always signal gastronomically fetishized exoticism however. Various Indigenous peoples consume still living animal proteins in the form of insects and larvae (the witchetty grubs that used to be a dietary staple in parts of Australia for instance), but for most Westerners, the practice of eating live food still signifies extreme otherness.

${ }^{17} \mathrm{He}$ had to have fish at every meal. When there weren't any live ones, he made do with the cadavers found in the market or in the supermarket freezer. It was sad, for in the nineteen years of my existence, we had never deigned to touch a dead fish.
} 
gobbled up this conventional meal (notwithstanding that the poultry was uncooked ${ }^{18}$ ), the narrator contrasts her care in preparing the bird and her father's devouring of what is only beginning to resemble food:

En disant cela, il avança d'un grand pas, me bousculant presque, ouvrit le four, prit le poulet, le déchira en deux et le mangea avec les os. Son geste fut si brutalement rapide que le poulait luisant de fraîcheur disparut en un éclair. Une légère tache de sang collait à un coin de ses lèvres tremblantes qui en ce moment me paraissaient étrangement épaisses et livides. (Chen 2006: 53$54)^{19}$

The drop of chicken blood elicits disgust and draws attention to the eater's cadaver-like features, which appear distorted by the sanguine remnant of his meal. The daughter, therefore, attempts to differentiate herself from her father: 'la férocité avec laquelle il avait consommé ... m’avait comme abattue, m’avait remise dans une réalité que je ne voulais pas reconnaître, dont je n’arrivais pas à me remettre aussitôt' (55). ${ }^{20}$ There is something in the way that food is consumed that, although in some ways natural for these animalistic characters, is also deeply disturbing. The fish-on-fish cannibalism exhibited by the father, but also by the daughter, can be rationalised as a normal feature of the food chain. However, the daughter's descriptions of the consumption of the chicken, and even the everyday meals of fish at the river, elicit from her (and through her narration for the reader) the kind of disgust that would usually be reserved for the most abject forms of eating.

In contrast to these monstrous devourings, the descriptions of the anthropophagic act are remarkable in that they present this event in detail, but manage to do so in a way that undercuts expectations and makes it more caring and considerate about that which is consumed than eating would normally be. Occupying the speaking position of both the 'meal in waiting' and the 'already eaten,' the narrator amplifies and complicates the justifications for cannibalism by establishing her own devouring as ethical in both a particular and universalist sense. Remembering her supernatural, time-travelling passage through her father's innards, the daughter constitutes her father's body as a

\footnotetext{
${ }^{18}$ The contrast of the raw ingredient and the prepared and cooked food echoes Levi-Strauss's use of this food-based differentiation in his discussion of nature and culture in The Raw and the Cooked (1969). The daughter's preference for raw (and live) food would surely see her at home in the contemporary raw food movement, which insists on the benefits of uncooked food.

${ }^{19}$ In saying that, he lunged forward, nearly shoving me out of the way, opened the oven, took the chicken, tore it in two and ate it bones and all. His movement was so brutally quick that the chicken, lustrous with freshness, disappeared in a flash. A small drop of blood clung to the corner of his trembling lips, which in this instant struck me as strangely thick and pallid.

${ }^{20}$ The ferocity with which he had consumed ... nearly bowled me over; it put me back into a reality that I did not want to recognise and from which I could not quickly recover.
} 
nurturing space akin to a mother's womb, referring to it as a home (Chen 2006: 115). At the same time as she expresses contempt for her father's penchant for eating the dead, she praises him for the consideration he shows to his living meals. She seems to take comfort in her father's assurances that he will gulp her down whole and not use his pointy, fish-like teeth: 'Pour m’éviter la douleur, me rassura-t-il, il n'allait pas utiliser ses dents effrayantes, devenues très aiguës avec l'âge. Il allait essayer de m'aspirer' (84). ${ }^{21}$ Reflecting on the event from the subject position of the already eaten, she marvels at the consideration afforded to her ingestion: 'Malgré tout je tiens à dire à mon père que j'ai adoré ma mort. C’était l'une des meilleures. La plus chaleureuse, naturelle et écologique' (77). ${ }^{22}$ Given the testimony that speaks of impossible empathy, the reader here is prompted to think about food from the perspective of the eaten. What care do we take when we eat? Would we cook and chew a carrot, a steak or a piece of bread if we recognized this food not just as having been sentient, but as literal kin that we had raised and cared for? These considerations make anthropophagy, that most taboo practice of eating associated with savage and barbarous behaviour, an ethical food practice because of the narrator's improbable ability to understand what it means to be (live) food.

The text's generic appearance as a surreal tale with exceptionally embodied characters facilitates the re-imagining of food ethics and proves intrinsic, and not incidental, to the process. Although food still plays a role in understanding who we are, Le Mangeur entreats us to consider this matter via new questions, such as whether or not cannibalism, contrary to dominant notions of 'civility,' is the proof of our humanity. In going beyond conventional narratives and characters and their use of food to indicate orders of belonging, Chen opens up ways, both broader and more specific, to conceive of our relationship to what we eat. By insisting on the questions that consumption raises rather than on what it represents, she makes it possible for food in cultural productions like (migrant) literature to do more than serve as a mere trope. This break with tradition acts as an important step in the evolution of the genre away from its anthropological or ethnographic orientation (Harel 2002).

\footnotetext{
${ }^{21}$ To spare me pain, he reassured me, he would not use his terrifying teeth, which had become very sharp with age. He would try to suck me up.

${ }^{22}$ Despite everything, I want to tell my father that I loved my death. It was one of the best; the most warm, natural and ecological.
} 


\section{Conclusion}

The ethics of eating that both the father and the dual-voiced narrator advocate is one that is anchored in their own embodiment and experience, not parental teaching, nor any other sense of culture, whether writ large or small. In embracing the most universal of food taboos and ethical imperatives relating to eating and in making embodied experience the basis for this reversal, Chen calls on her reader to reconsider the priority we ascribe to culture when it comes to making sense of food choices. With nothing to anchor their sense of the edible save their embodiments, the fantastical characters and their semantically rich hybridity invite reflection on the role of food in telling us who we are, especially in relation to those who most resemble us.

Le Mangeur reminds us that eating exists in a complex relationship, not (just) with culture and tradition but first and foremost with ourselves as eaters. Chen's ambiguous and radically different characters defy conventions relating to food in writing by migrant authors, undermine moralistic conceptions of food ethics that are operative in contemporary society and challenge the overall contention that the food we eat is emblematic of identity. Instead, food emerges as a locus for reflexive and negotiated understandings of who we are. Chen's provocative evocations of eating remind us that food is not simply a reflection of difference or a means to establish belonging. Rather, food is a means of understanding our embodied situation and the needs that stem from it, of negotiating how we resemble and how we stand apart not only from other eaters, but also from what we consume.

\section{Reference List}

Anderson, N. 2010, 'The "Ethics” of Consensual Cannibalism: Deconstructing the Human-Animal Dichotomy,' Antennae, vol 1: 65-74.

Ang, I. 2004, 'Between Asia and the West: The Cultural Politics of Food,' Life Writing, vol. 1, no. 1: $147-54$.

Brillat-Savarin, J. A. 1826. Physiologie du gout ou Méditation de gastronomie transcendante. Sautelet: Paris.

Chen, Y. 1993, Les Lettres chinoises. Lemeac, Montreal. 2003, Querelle d'un squelette avec son double. Boréal, Montreal. 2006, Le Mangeur. Boréal, Montreal.

Derrida, J. 1991, “"Eating Well,” or the Calculation of the Subject: An Interview with Jacques Derrida,' trans. Peter Connor \& Avital Ronell in Who Comes After the Subject?, (eds) E. Cadava, P. Connor \& J.-L. Nancy. Routledge, New York: 96-119.

Diprose, R. 1994, The Bodies of Women: Ethics, Embodiment, and Sexual Difference. Routledge: London. 1995, ‘A “Genethics” That Makes Sense,’ in Biopolitics: A Feminist and Ecological Reader on Biotechnology (eds) V. Shiva \& I. Moser. Zed Books, London: 162-74

Douglas, M. (ed.) 1984, Food in the Social Order: Studies of Food and Festivities in Three American Communities. Russell Sage Foundation, New York. 
Finn, S. M. 2011, Aspirational Eating: Class Anxiety and the Rise of Food in Popular Culture, Unpublished Doctoral Dissertation, University of Michigan, Ann Arbor.

Flowers, R. \& Swan, E. 2012, 'Eating the Asian Other? Pedagogies of Food and Multiculturalism in Australia,' Portal Journal of Multidisciplinary International Studies, vol 9, no. 2. Online, available: http://epress.lib.uts.edu.au/journals/index.php/portal/article/view/2370 [Accessed 29 March 2013].

Foucault, M. 1997, Ethics: Subjectivity and Truth, (ed) Paul Rabinow. New Press: New York.

Goldman, A. 1992, “”I Yam What I Yam”: Cooking, Culture and Colonialism' in Decolonizing the Subject: The Politics of Gender in Women's Autobiography, (eds) Sidonie Smith \& Julia Watson. University of Minnesota Press, Minneapolis: 169-95.

Guest, K. 2001, 'Introduction: Cannibalism and the Boundaries of Identity,' in Eating Their Words: Cannibalism and the Boundaries of Cultural Identity, (ed.) K. Guest. State University of New York Press, Albany: 1-9.

Harel, S. 2002, 'Une littérature des communautés culturelles made in Québec?,' Globe: Revue internationale d'études québécoises, vol 5, no. 2: 57-77.

hooks, b. 1992, 'Eating the Other,' in Black Looks: Race and Representation. South End Press, Boston: 21-39.

Heller, T. \& Moran, P. 2003, 'Introduction: Scenes of the Apple: Appetite, Desire, Writing' in Scenes of the Apple: Food and the Female Body in Nineteenth- and Twentieth-Century Women's Writing, (eds) T. Heller \& P. Moran. State University of New York Press, Albany: 1-42.

Hubbell, A. 2013, ‘(In)Edible Algeria: Transmitting Pied-Noir Nostalgia Through Food,’ Portal Journal of Multidisciplinary International Studies, vol. 10, no. 2: in this Special Issue.

Johnston, J. \& Baumann, S. 2010, Foodies: Democracy and Distinction in the Gourmet Foodscape. Routledge, New York.

Johnston, J., Szabo, M. \& Rodney, A. 2011, 'Good Food, Good People: Understanding the Cultural Repertoire of Ethical Eating,’ Journal of Consumer Culture, vol. 11, no. 3: 293-18.

Kitson, P. J. 2000, “"The Eucharist of Hell”; or, Eating People is Right: Romantic Representations of Cannibalism”, Romanticism on the Net, vol. 17, February. Online, available : www.erudit.org/revue/ron/2000/v/n17/005892ar.html [accessed 31 August 2012].

Leder, D. 1990, The Absent Body. University of Chicago Press: Chicago.

Levi-Strauss, C. 1969, The Raw and the Cooked: Introduction to a Science of Mythology I. Trans. J. Weightman \& D. Weightman. Jonathan Cape, London.

Lorre, C. 2009, 'Qui dit “je” dans Le Mangeur de Ying Chen? Une lecture entre psychanalyse et pensée,’ Nouvelles études francophones, vol. 24, no. 1: 19-30.

Mata-Barriero, C. 2003, 'L’Univers gustative et la construction de l'identité dans l'écriture migrante,' Revue des lettres et de traduction, vol. 9: 291-305.

Parsons, T. 1951, The Social System. Free Press of Glencoe, Glencoe, IL.

Probyn, E. 1999, 'Beyond Food/Sex: Eating and an Ethics of Existence,' Theory, Culture, Society, vol. 16, no. 2: 215-28.

Pugh, T. 2008, ““Are We Cannibals, Let Me Ask? Or are We Faithful Friends?”: Food, Interspecies Cannibalism, and the Limits of Utopia in L. Frank Baum’s Oz Books,' The Lion and the Unicorn, vol. 3: 324-43.

Saint-Martin, L. 2010, Au delà du nom: La question du père dans la littérature québécoise actuelle. Presses de l’Université de Montréal, Montreal.

Sceats, S. 2000 Food Consumption \& The Body in Contempoary Women's Fiction. Cambridge University Press, Cambridge.

Simmel, G. 1994, 'The Sociology of the Meal,' trans. Michael Symons, Food and Foodways, vol. 5, no. 4: 345-50.

Symons, M. 1994, 'Simmel’s Gastronomic Sociology: An Overlooked Essay,' Food and Foodways, vol. 5, no. 4: 333-51.

Yaeger, J. A. 2004, 'Bach Mai and Ying Chen: Immigrant Identities in Quebec,' in Textualizing The Immigrant Experience In Contemporary Quebec, (eds) S. Ireland \& P. J. Proulx. Praeger, Westport, CT: 137-48.

Yue, G. 1999, The Mouth That Begs: Hunger, Cannibalism and the Politics of Eating in Modern China. Duke University Press, Durham, NC. 